\title{
The influence of casein haplotype on quality, coagulation, and yield traits of milk from Italian Holstein cows
}

\author{
Annamaria Perna, ${ }^{1}$ Immacolata Intaglietta, Emilio Gambacorta, and Amalia Simonetti \\ School of Agricultural, Forestry, Food and Environmental Sciences, University of Basilicata, Potenza, Viale dell'Ateneo Lucano 10-85100, Italy
}

\begin{abstract}
The aim of this work was to investigate the effect of casein haplotype (CSN1S1, CSN2, and CSN3) on quality, coagulation, and yield traits of milk from Italian Holstein cows. The casein haplotype was determined by isoelectric focusing; milk clotting properties were determined by using a mechanical lacto-dynamographic instrument; and the yields of pressed and pasta filata cheeses were expressed as kilograms of cheese per 100 $\mathrm{kg}$ of milk processed. Statistical analysis showed a significant effect of the casein haplotype. In particular, $B B-A^{1} A^{1}-A A$ milk showed the highest fat content (4.01 $\mathrm{g} / 100 \mathrm{~g}$ ), whereas $B B-A^{2} A^{2}-B B$ milk had a higher protein content, the best coagulation characteristics, and the highest yields in pressed and pasta filata cheeses, and, consequently, better ability to retain fat and protein in the curd. The results of this study suggest that knowledge of milk protein polymorphisms not only allows the production of milk with specific qualitative and quantitative characteristics, but it could also be used as a specific marker within a breed to identify milk suitable for cheesemaking, which confers an economical advantage for dairy producers.
\end{abstract}

Key words: casein haplotype, milk quality, coagulation and yield traits, Italian Holstein cows

\section{INTRODUCTION}

In many milk-producing countries, such as France, Greece, and Italy, a large part of the total milk produced is used for cheese making. In Italy, many specialized structures in the dairy industry produce different typical and traditional cheeses, in particular Protected Designation of Origin products, such as Grana Padano, Parmigiano Reggiano, Gorgonzola, and Asiago cheeses (Pieri, 2010). Currently, about $70 \%$ of product milk in Italy is destined to cheesemaking, and approximately $50 \%$ of this fraction is used for Protected Designation of

Received September 29, 2015.

Accepted January 20, 2016.

${ }^{1}$ Corresponding author: anna.perna@unibas.it
Origin products (Agriculture and Rural Development, 2015). The amount and quality of cheese obtained per volume unit of milk processed are important for the profitability of the dairy industry. Milk coagulation properties (MCP) are considered good indicators of both the quality and yield of cheese (Bittante, 2011), and they are commonly measured as rennet coagulation time (RCT, min), curd-firming rate $\left(\mathbf{k}_{\mathbf{2 0}}, \mathbf{m i n}\right)$, and curd firmness $\left(\mathbf{a}_{\mathbf{3} 0}, \mathrm{~mm}\right)$. However, milk clotting properties are affected by various factors, such as total casein and calcium concentrations (Storry et al., 1983), pH (Najera et al., 2003), SCC (Politis and Ng-KwaiHang, 1988), genetic polymorphism of milk proteins (Schaar et al., 1985; Mayer et al., 1997; Ikonen et al., 1999), stage of lactation (Okigbo et al., 1985; Ostersen et al., 1997), season (O'Brien et al., 1999), and breed (Auldist et al., 2002, 2004; De Marchi et al., 2008).

Many authors have shown that genetic variants of milk proteins affect both absolute (Ikonen et al., 1997; Hallén et al., 2008) and relative concentrations (Bobe et al., 1999; Heck et al., 2009; Bonfatti et al., 2010) of the individual milk proteins. In particular, the most consistent effect was found for CSN3 $(\kappa-\mathrm{CN})$ variant $\mathrm{B}$, which has been shown to have a positive effect on ఓ-CN concentration of milk (Bobe et al., 1999; Hallén et al., 2008; Heck et al., 2009), and it was associated with smaller average casein micelle size (Walsh et al., 1998a), the better coagulating properties, and a higher cheese yield variation in casein micelle size (Mayer et al., 1997; Ng-Kwai- Hang, 1998), whereas the CSN2 polymorphism was found to be related to fat percentage and fat and protein yields (Bovenhuis et al., 1992; Ikonen et al., 1999). However, the effects of casein haplotypes on milk clotting properties and cheese yield were evaluated considering a single locus (Aleandri et al., 1990; Bovenhuis et al., 1992). Many authors (Ojala et al., 1997; Braunschweig et al., 2000) instead suggested that the effects of individual locus are confounded in statistical analyses, even when they are included simultaneously in the model, because their influence on milk traits could be due to the cumulative effect of different casein loci on chromosome 6 . Consequently, it is believed that a better estimation of effects of casein 
genotypes is obtained by studying whole combinations of alleles (casein cluster) rather than single alleles due to the tight genetic linkage among casein loci (Gambacorta et al., 1994, 2005; Boettcher et al., 2004).

The objective of this study was to evaluate the effect of casein haplotype on quality, coagulation, and yield traits of milk from Italian Holstein cows.

\section{MATERIALS AND METHODS}

\section{Samples}

This study was conducted on an intensive farm, consisting of more than 500 Italian Holstein cows, in the countryside of Potenza, southern Italy. Before starting the test, about 250 animals in lactation were identified by isoelectric focusing (IEF) to define their haplotypes. Haplotypes were formed by the combination of the individual allelic loci aggregated by CSN1S1, CSN2, and CSN3 $\left(\alpha_{\mathrm{S}^{-}}, \beta-\right.$, and $\kappa_{-} \mathrm{CN}$, respectively). After definition of individual phenotypes, the cows were grouped by haplotype. Each group included 10 to 12 animals, at an equal stage of lactation (70 to $120 \mathrm{~d}$ postpartum), season (spring), and order of birth (third calving). All animals were fed a commercial standard diet according to milk yield. The individual cow milk of the morning milking was collected once and all milk samples were stored at $4^{\circ} \mathrm{C}$ until analysis.

\section{Sample Preparation for IEF}

Individual milk samples, kept at $4^{\circ} \mathrm{C}$, were defatted by centrifugation $\left(3,000 \times g\right.$ for $30 \mathrm{~min}$ at $\left.4^{\circ} \mathrm{C}\right)$; the fat layer was solidified at $-20^{\circ} \mathrm{C}$ for $20 \mathrm{~min}$ and removed. Casein was prepared by isoelectric precipitation at $\mathrm{pH}$ 4.6 with $10 \%$ ( $\mathrm{vol} / \mathrm{vol}$ ) acid acetic and $1 M$ sodium acetate at room temperature. After centrifugation at $3,000 \times g$ for $10 \mathrm{~min}$ at $4^{\circ} \mathrm{C}$, the casein pellet was washed twice with distilled water and stored at $-20^{\circ} \mathrm{C}$. The whole casein was dissolved in $9 \mathrm{M}$ urea and $1 \%$ 2-mercaptoethanol for IEF analysis, according to Aschaffenburg and Drewry (1959).

\section{Genetic Variants of Caseins by IEF}

The genetic variants of the different caseins by IEF were determined according to the method of Trieu-Cuot and Gripon (1981). The IEF analysis was performed on polyacrylamide gel $(5 \%$ acrylamide and $0.15 \%$ bisacrylamide) with a thickness of $1 \mathrm{~mm}$ and $2 \%$ carrier ampholytes to create a gradient of $\mathrm{pH} 2.5$ to 10 . The gel was prefocused at a constant value of $0.35 \mathrm{~W} / \mathrm{mL}$ of gel and at the maximum limit of 1,200 V. The gel was stained in Coomassie Brilliant Blue G-250 according to
Blakesley and Boezi (1977). Haplotype frequencies were determined by the number of each haplotype $\left(\mathrm{n}_{i}\right)$ divided by the total number of haplotypes $\left(\mathrm{n}_{\text {tot }}\right)$ : Frequency $(\%)=\left(\mathrm{n}_{i \text {, haplotype }} / \mathrm{n}_{\text {tot, haplotype }}\right) \times 100$. Haplotypes are presented in the order CSN1S1-CSN2-CSN3.

\section{Compositional Analysis}

Milk and whey samples were analyzed for DM, total protein (total $\mathrm{N} \times 6.38$; by Kjeldahl method), ash (AOAC International, 2000), fat (Röse-Gottlieb method; IDF, 1996), and lactose (IDF, 1974). The $\mathrm{pH}$ was measured using a pH meter (model PHM 92, Radiometer, Copenhagen, Denmark) after calibrating with fresh $\mathrm{pH} 4.0$ and 7.0 standard buffers. Milk SCC were determined by fluoro-opto-electronic method (SchmidtMadsen, 1975), with a Fossomatic 250 (Foss Electric, Hillerød, Denmark).

\section{Analysis of Milk Clotting Properties}

Milk clotting properties were determined by mechanical lacto-dynamographic instrument (Formagraph, Foss, Padova, Italy) as previously described by CipolatGotet et al. (2012). In brief, each individual milk sample $(10 \mathrm{~mL})$ was heated to $35^{\circ} \mathrm{C}$ before the addition of 200 $\mu \mathrm{L}$ of the rennet solution [Hansen Naturen Plus 215 (Pacovis Amrein AG, Bern, Switzerland), with $80 \pm$ $5 \%$ chymosin and $20 \pm 5 \%$ pepsin and 215 international milk clotting units (IMCU) $/ \mathrm{mL}$, which was diluted to $1.2 \%$ (wt/vol) in distilled water to achieve 0.0513 $\mathrm{IMCU} / \mathrm{milk} \mathrm{mL}]$. The lacto-dynamograph recorded the width $(\mathrm{mm})$ of the oscillatory graph every $15 \mathrm{~s}$ throughout the extended observation period (min after rennet addition). Traditional MCP parameters were provided directly by the instrument, including RCT (min), $\mathrm{k}_{20}$ (min), and $\mathrm{a}_{30}(\mathrm{~mm})$.

\section{Cheese Yield}

Each milk sample was cheesemaking for both pasta filata and pressed paste cheeses. Briefly, 2 L of milk was heated to $37^{\circ} \mathrm{C}$ and coagulated by using lamb rennet paste $(177 \mathrm{IMCU} / \mathrm{mL} ; 40.0 \mathrm{mg} / \mathrm{kg}$ ) for 30 to 40 min. Then, for pasta filata cheese, the coagulum was first cut coarsely, heated under whey at $45^{\circ} \mathrm{C}$ for $2 \mathrm{~h}$, reduced to particles of about $1.5 \mathrm{~cm}$, and held at room temperature until the $\mathrm{pH}$ reached approximately 5.3. When the acidified curd was ready, it was manually stretched in hot water $\left(70-80^{\circ} \mathrm{C}\right)$. For pressed paste cheese, the coagulum was first cut coarsely, held under whey at $37^{\circ} \mathrm{C}$ for $2 \mathrm{~h}$, and reduced to particles of about $1.5 \mathrm{~cm}$. Finally, the whey was removed and the curd was pressed. Cheese yield was expressed as kilograms 
of cheese per $100 \mathrm{~kg}$ of milk processed. All cheeses were stored at 10 to $12^{\circ} \mathrm{C}$ and 75 to $80 \%$ relative humidity and weighed after $24 \mathrm{~h}$.

\section{Statistical Analysis}

Data were analyzed according to the following linear model (SAS Institute, 1996):

$$
\mathrm{y}_{i k}=\mu+\alpha_{i}+\varepsilon_{i k},
$$

where $\mathrm{y}_{i k}$ is the observation; $\mu$ is the overall mean; $\alpha_{i}$ is the fixed effect of the $i$ th haplotype $(i=1,2,3$, $4,5)$; and $\varepsilon_{i k}$ is the random error. Before setting the values, expressed as percentages, they were subjected to angular transformation. Student's $t$-test was used for all variable comparisons. Differences between means at the $95 \%(P<0.05)$ confidence level were considered statistically significant.

\section{RESULTS AND DISCUSSION}

\section{Haplotype Frequencies}

In the study population, 5 different casein haplotypes were identified by IEF. The different allelic combinations of loci CSN1S1, CSN2, and CSN3 and their frequencies are reported in Table 1. Haplotypes $B B$ $A^{2} A^{1}-A A, B B-A^{2} A^{2}-A A$, and $B B-A^{2} A^{2}-A B$ showed the highest frequency $(>28 \%)$, followed by haplotype $B B$ $A^{2} A^{2}-B B(7.89 \%)$, and haplotype $B B-A^{1} A^{1}-A A$ showed the lowest frequency $(<5 \%)$. In the Italian Holstein breed, the selection boost carried out only for specific aspects related to some phenotypic characteristics of milk (e.g., fat and protein yields) led to a reduction of the variability of allelic combinations.

\section{Chemical Composition}

Casein haplotype is closely associated with milk quality (Ng-Kwai Hang et al., 1986; Boettcher et al., 2004; Gambacorta et al., 2005). The ANOVA showed a significant effect of casein haplotype on all evaluated

Table 1. Frequencies of the $\alpha_{\mathrm{S1}^{-}}, \beta$-, and $\kappa_{-} \mathrm{CN}$ haplotypes in Italian Holstein milk

\begin{tabular}{lc}
\hline $\begin{array}{l}\text { Haplotype } \\
\text { (CSN1S1-CSN2-CSN3) }\end{array}$ & $\begin{array}{c}\text { Frequency } \\
(\%)\end{array}$ \\
\hline$B B-A^{2} A^{1}-A A$ & 30.13 \\
$B B-A^{2} A^{2}-A A$ & 29.09 \\
$B B-A^{2} A^{2}-A B$ & 28.41 \\
$B B-A^{2} A^{2}-B B$ & 7.89 \\
$B B-A^{1} A^{1}-A A$ & 4.47 \\
\hline
\end{tabular}

parameters $(P<0.01)$. The physicochemical composition and SCC of milk with different casein haplotypes is shown in Table 2. Dry matter content ranged between $12.44 \mathrm{~g} / 100 \mathrm{~g}\left(B B-A^{2} A^{2}-A B\right.$ milk $)$ and 13.01 $\mathrm{g} / 100 \mathrm{~g}\left(B B-A^{2} A^{2}-B B\right.$ milk); the differences among studied samples were not significant. The $B B-A^{1} A^{1}-A A$ milk showed the highest fat content $(4.01 \mathrm{~g} / 100 \mathrm{~g} ; P$ $<0.05)$, in agreement with that reported by Ikonen et al. (2001) in Finnish Ayrshire milk. Many studies have highlighted the influence of CSN2 genotype on fat content: Ng-Kwai-Hang et al. (1986) showed that milk with the $A^{1} A^{1}$ genotype showed a greater fat content, whereas Kiddy et al. (1970) observed a higher fat content in milk with the $A^{2} A^{2}$ genotype. Other authors (Aleandri et al., 1990; Van Eenennaam and Medrano, 1991) revealed no significant difference among casein genotypes for either fat or protein. Relative to the influence of CSN3 genotype on fat and protein, many authors (Ng-Kwai-Hang et al., 1986; Strzalkowska et al., 2002; Ng-Kwai-Hang and Grosclaude, 2003) reported the superiority of variant $\mathrm{B}$ compared with variant $\mathrm{A}$. In our study, $B B-A^{2} A^{2}-B B$ milk showed a higher total protein content $(3.61 \mathrm{~g} / 100 \mathrm{~g})$, differing statistically $(P<0.05)$ from that of $B B-A^{2} A^{2}-A B$ and $B B-A^{1} A^{1}-A A$ milk. These findings are in disagreement with Matassino et al. (2002), who found that, in Italian Holstein cows, $B B-A^{2} A^{1}-A A$ milk showed a greater protein content, whereas, in Brown cows, $B B-A^{1} A^{1}-B B$ milk had the highest protein content. Boettcher et al. (2004) found the highest protein content in $B B-A^{1} A^{1}$ $B B$ milk in both Holstein and Brown cows. Many authors also detected a positive correlation between protein content and the $B$ allele of CSN3 (Bovenhuis et al., 1992; Bovenhuis and Weller, 1994) and the $A^{2}$ allele of CSN2 (Bech and Kristiansen, 1990; Velmala et al., 1995; Freyer et al., 1998). Lactose content was highest in $B B-A^{2} A^{2}-A A$ and $B B-A^{2} A^{1}-A A$ milks (4.87 and 4.91 g/100 g, respectively; $P<0.05)$, whereas $B B-A^{1} A^{1}-A A$ milk showed the lowest content $(4.43 \mathrm{~g} / 100 \mathrm{~g} ; P<$ 0.05). Conversely, Matassino et al. (2002) detected the highest lactose content in $B B-A^{2} A^{2}-B B$ milk. Concerning ash content, $B B-A^{1} A^{1}-A A$ and $B B-A^{2} A^{1}-A A$ milks showed the highest content $(0.77$ and $0.76 \mathrm{~g} / 100 \mathrm{~g}$, respectively; $P<0.05$ ). Statistical analysis highlighted a significant effect of casein haplotype on $\mathrm{pH}$, in agreement with Matassino et al. (2002). In particular, the $\mathrm{pH}$ value ranged between 6.54 in $B B-A^{2} A^{2}-A B$ milk and 6.81 in $B B-A^{1} A^{1}-A A$ milk; significant differences $(P<0.05)$ were found among milks with different casein haplotype. All studied milk samples showed a mean SCC lower than the limit set by the "Hygiene Package" by the Regulation European Commission (Reg. EC 853/2004; $400 \times 10^{3}$ cells/mL; Regulation EC 853/2004; EC, 2004). In particular, $B B-A^{2} A^{2}-A B$ 
Table 2. Physicochemical composition (g/100 g, unless otherwise noted) and SCC of Italian Holstein milk with different casein haplotypes

\begin{tabular}{|c|c|c|c|c|c|c|c|c|c|c|}
\hline Item & \multicolumn{10}{|c|}{ Haplotype (CSN1S1-CSN2-CSN3) } \\
\hline$\overline{\mathrm{DM}}$ & $12.44^{\mathrm{a}}$ & 0.36 & $13.01^{\mathrm{a}}$ & 1.11 & $12.72^{\mathrm{a}}$ & 0.52 & $12.53^{\mathrm{a}}$ & 0.68 & $12.72^{\mathrm{a}}$ & 0.39 \\
\hline Fat & $3.60^{\mathrm{a}}$ & 0.07 & $3.86^{\mathrm{a}}$ & 0.55 & $3.68^{\mathrm{a}}$ & 0.35 & $4.01^{\mathrm{b}}$ & 0.55 & $3.58^{\mathrm{a}}$ & 0.27 \\
\hline Total protein & $3.33^{\mathrm{a}}$ & 0.18 & $3.61^{\mathrm{b}}$ & 0.12 & $3.43^{\mathrm{ab}}$ & 0.26 & $3.32^{\mathrm{a}}$ & 0.13 & $3.45^{\mathrm{ab}}$ & 0.19 \\
\hline $\mathrm{pH}$ & $6.54^{\mathrm{a}}$ & 0.03 & $6.66^{\mathrm{b}}$ & 0.04 & $6.74^{\mathrm{c}}$ & 0.06 & $6.81^{\mathrm{d}}$ & 0.01 & $6.75^{\mathrm{c}}$ & 0.05 \\
\hline SCC $\left(10^{3}\right.$ cells $\left./ \mathrm{mL}\right)$ & $49.00^{\mathrm{a}}$ & 4.97 & $71.75^{\mathrm{b}}$ & 19.96 & $48.83^{\mathrm{a}}$ & 17.29 & $99.50^{\mathrm{c}}$ & 2.12 & $76.20^{\mathrm{b}}$ & 24.01 \\
\hline
\end{tabular}

${ }^{\mathrm{a}-\mathrm{d}}$ Means within a column with different superscripts differ $(P<0.05)$.

and $B B-A^{2} A^{2}-A A$ milks showed the lowest SCC $(49.00$ $\times 10^{3}$ and $48.50 \times 10^{3}$ cells $/ \mathrm{mL}$, respectively; $P<0.05$ ) compared with other studied samples.

\section{Milk Clotting Properties}

The MCP parameters of Italian Holstein milk with different casein haplotype are reported in Table 3. Rennet coagulation time, $\mathrm{k}_{20}$, and $\mathrm{a}_{30}$ parameters were significantly influenced by casein haplotype $(P<0.05)$, in agreement with results reported by Caroli et al. (2009), who affirmed that both the quantitative (linked to the single genetic mutation) and qualitative variations (linked to different capacity of expression of alleles that control the synthesis of individual caseins and to the interactions among closely associated loci) markedly affect the enzymatic phase and the physicochemical performance of rennet coagulation. Overall, RCT and $\mathrm{k}_{20}$ values ranged between 14.45 and $17.78 \mathrm{~min}$, and between 5.83 and $10.92 \mathrm{~min}$, respectively, whereas the $\mathrm{a}_{30}$ value ranged between 21.25 and $38.80 \mathrm{~mm}$. All milk samples were classified as type A (optimal milk) according to the classification proposed by Zannoni and Annibaldi (1981). In particular, $B B-A^{2} A^{2}-A B$ and $B B-A^{2} A^{2}-B B$ milks showed the lowest RCT value $(P<$ $0.05)$; furthermore, the last haplotype $\left(B B-A^{2} A^{2}-B B\right)$ showed the best coagulation characteristics, presenting the lowest $\mathrm{k}_{20}$ value $(P<0.05)$ and the highest $\mathrm{a}_{30}$ value $(P<0.05)$. In contrast, $B B-A^{1} A^{1}-A A$ milk showed the highest $\mathrm{k}_{20}$ value $(P<0.05)$ and the lowest $\mathrm{a}_{30}$ value $(P$ $<0.05$ ), in disagreement with Marziali and Ng-KwaiHang (1986), who reported that CSN2 $A^{1} A^{1}$ milk showed the best coagulation characteristics. Our findings are in agreement with those of Summer et al. (2004), who detected that milk with a lower curd-firming time $\left(\mathrm{k}_{20}\right)$ showed better curd firmness $\left(\mathrm{a}_{30}\right)$. Within the CSN3 locus, for CSN1S1 variant $B B$ and CSN2 variant $A^{2} A^{2}$, $B B-A^{2} A^{2}-A A$ milk showed the worst MCP values $(P<$ $0.05)$. The best coagulation characteristics of CSN3 $B B$ milk compared with CSN3 $A A$ milk were demonstrated by Nuyts-Petit et al. (1997) in Normande cows and by Walsh et al. (1998a) in Irish Holstein cows; this was due to the lower loss of casein and fat of CSN3 $B B$ milk during cheesemaking (Hartung and Gernand, 1997; Pabst, 1998; Walsh et al., 1998b). Mariani and Summer (1999) and Mariani et al. (2002) also reported that CSN3 $B B$ milk is characterized by a higher CSN3 content and by smaller casein micelles.

\section{Cheese Yield and Whey Composition}

Yields of pressed and pasta filata cheeses obtained from Italian Holstein milk for the different casein haplotypes is shown in Figure 1. Overall, casein haplo-

Table 3. Milk coagulation properties of Italian Holstein milk with different casein haplotypes ${ }^{1}$

\begin{tabular}{|c|c|c|c|c|c|c|}
\hline \multirow{2}{*}{$\begin{array}{l}\text { Haplotype } \\
\text { (CSN1S1-CSN2-CSN3) }\end{array}$} & \multicolumn{2}{|c|}{$\mathrm{RCT}(\min )$} & \multicolumn{2}{|c|}{$\mathrm{k}_{20}(\min )$} & \multicolumn{2}{|c|}{$\mathrm{a}_{30}(\mathrm{~mm})$} \\
\hline & Mean & $\mathrm{SD}$ & Mean & $\mathrm{SD}$ & Mean & $\mathrm{SD}$ \\
\hline$\overline{B B-A^{2} A^{2}-A B}$ & $14.79^{\mathrm{a}}$ & 0.41 & $8.12^{\mathrm{a}}$ & 0.73 & $35.36^{\mathrm{a}}$ & 0.89 \\
\hline$B B-A^{2} A^{2}-B B$ & $14.45^{\mathrm{a}}$ & 0.61 & $5.83^{\mathrm{b}}$ & 0.44 & $38.80^{\mathrm{b}}$ & 0.87 \\
\hline$B B-A^{2} A^{2}-A A$ & $17.78^{\mathrm{b}}$ & 0.77 & $10.92^{\mathrm{c}}$ & 0.40 & $27.52^{\mathrm{c}}$ & 1.11 \\
\hline$B B-A^{1} A^{1}-A A$ & $17.20^{\mathrm{b}}$ & 0.79 & $13.55^{\mathrm{d}}$ & 0.78 & $21.25^{\mathrm{d}}$ & 1.34 \\
\hline$B B-A^{2} A^{1}-A A$ & $16.31^{\mathrm{c}}$ & 0.74 & $10.13^{\mathrm{e}}$ & 0.47 & $30.38^{\mathrm{e}}$ & 1.37 \\
\hline
\end{tabular}

${ }^{\mathrm{a} e}$ Means within a column with different superscripts differ $(P<0.05)$.

${ }^{1} \mathrm{RCT}=$ rennet coagulation time; $\mathrm{k}_{20}=$ curd-firming rate; $\mathrm{a}_{30}=$ curd firmness. 


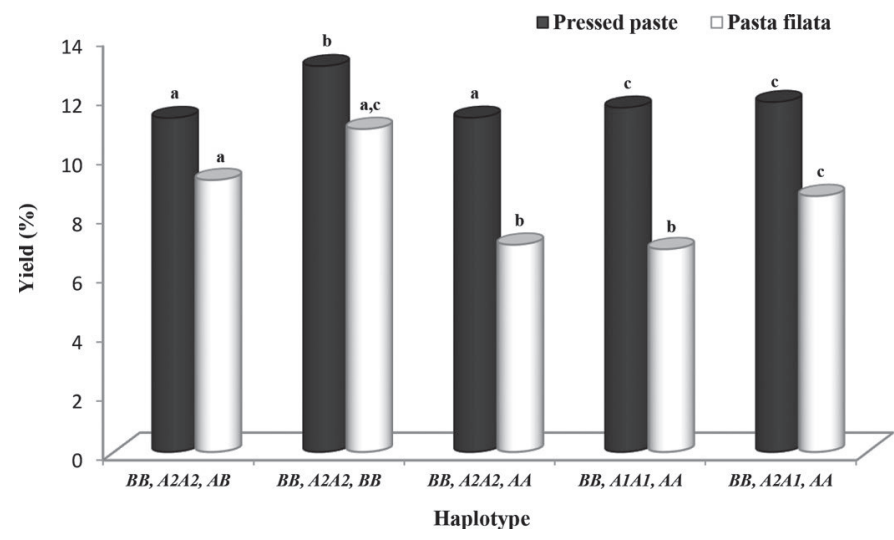

Figure 1. Yield of pressed and pasta filata cheeses obtained from Italian Holstein milk for different casein haplotypes (CSN1S1, CSN2, and CSN3, respectively). Means within the same cheese type with different letters $(\mathrm{a}-\mathrm{c})$ differ $(P<0.05)$.

type significantly affected cheese yield $(P<0.01)$. In particular, $B B-A^{2} A^{2}-B B$ milk showed the highest yield of both pressed and pasta filata cheeses (13.05 and $10.93 \%$, respectively), in agreement with that reported by other authors (Marziali and Ng-Kwai-Hang, 1986; Rahali and Ménard, 1991; Nuyts-Petit et al., 1997) who showed, in many pressed cheeses, that the highest yield was obtained from CSN3 variant BB milk. The $B B-A^{2} A^{2}-A B$ and $B B-A^{2} A^{2}-A A$ milks showed, instead, the lowest yields of pressed cheese (11.30 and $11.31 \%$, respectively; $P<0.05)$, whereas $B B-A^{2} A^{2}-A A$ and $B B$ $A^{1} A^{1}-A A$ milks presented the lowest yield of pasta filata cheeses (7.03 and $6.88 \%$, respectively; $P<0.05)$. In this study, we also reported fat and protein contents in

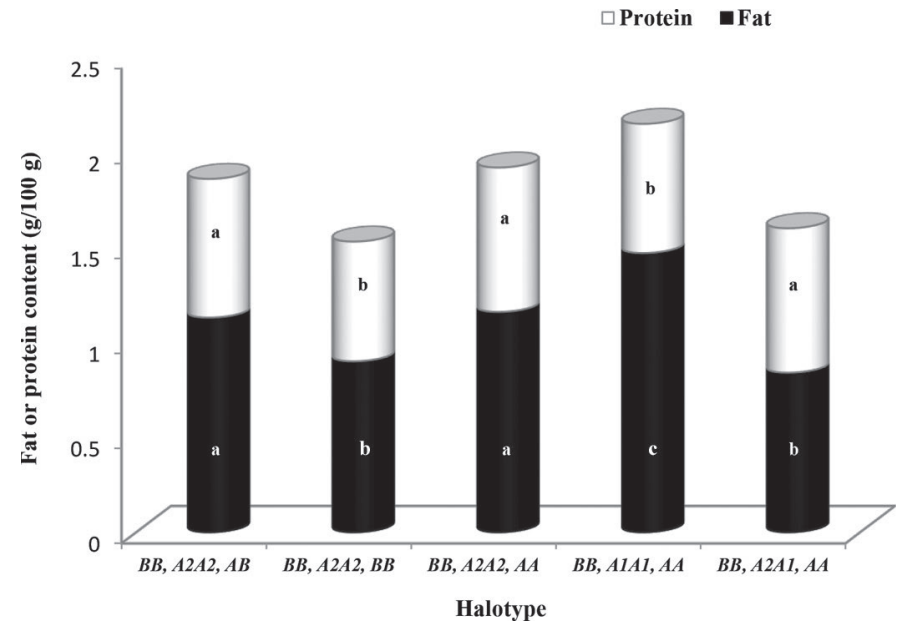

Figure 2. Fat and protein contents in whey after cheesemaking for different casein haplotypes (CSN1S1, CSN2, and CSN3, respectively). Means within the same parameter (fat or protein) with different letters $(\mathrm{a}-\mathrm{c})$ differ $(P<0.05)$ whey after cheesemaking for the different casein haplotypes (Figure 2), because the whey is considered a good indicator of the milk's ability to transfer its components to cheese (Walsh et al., 1998a; Ikonen et al., 1999; Johnson et al., 2001; Summer et al., 2004). Within the CSN3 locus, for CSN1S1 variant $B B$ and CSN2 variant $A^{2} A^{2}, B B-A^{2} A^{2}-B B$ whey showed the lowest fat and protein contents $(0.90$ and $0.63 \mathrm{~g} / 100 \mathrm{~g}$, respectively; $P<0.05)$ compared with $B B-A^{2} A^{2}-A B(1.13$ and 0.73 $\mathrm{g} / 100 \mathrm{~g})$ and $B B-A^{2} A^{2}-A A$ (11.16 and $0.76 \mathrm{~g} / 100 \mathrm{~g}$ ) whey. These findings are in agreement with reports of other authors, who detected that CSN3 AA milk had a higher fat content in whey after processing of Cheddar (Walsh et al., 1998a), Gouda (van den Berg, 1992), and Mozzarella (Walsh et al., 1998b) cheese compared with CSN3 $B B$ milk. Within the CSN2 locus, for CSN1S1 variant $B B$ and $\mathrm{CSN} 3$ variant $A A, B B-A^{1} A^{1}-A A$ whey showed the highest fat $(1.47 \mathrm{~g} / 100 \mathrm{~g} ; P<0.05)$ and the lowest protein $(0.68 \mathrm{~g} / 100 \mathrm{~g} ; P<0.05)$ content compared with $B B-A^{2} A^{1}-A A(0.84$ and $0.76 \mathrm{~g} / 100 \mathrm{~g}$, respectively) and $B B-A^{2} A^{2}-A A(1.16$ and $0.76 \mathrm{~g} / 100 \mathrm{~g}$, respectively) whey. Marziali and Ng-Kwai-Hang (1986) reported that $\mathrm{CSN} 2 A^{1} A^{1}$ milk showed a higher capacity to retain protein in coagulum during cheesemaking than did CSN2 $A^{2} A^{1}$.

\section{CONCLUSIONS}

Casein haplotype influenced both milk composition and cheese yield traits. In particular, $B B-A^{2} A^{2}-B B$ milk was particularly suitable for production of pressed and pasta filata cheeses, because it showed higher fat and protein contents, the best coagulation characteristics and highest cheese yield, and better ability to retain fat and protein in the curd. Knowledge of milk protein polymorphisms not only allows the production of milk with specific qualitative and quantitative characteristics, but it could also be used as a specific marker within a breed to identify milk suitable for cheesemaking, which confers an economical advantage for dairy producers.

\section{REFERENCES}

Agriculture and Rural Development. 2015. Milk and milk products. Accessed May 2015. http://ec.europa.eu/agriculture/milk/index_ en.htm.

Aleandri, R., L. G. Buttazzoni, J. C. Schneider, A. Caroli, and R. Davoli. 1990. The effects of milk protein polymorphisms on milk components and cheese-producing ability. J. Dairy Sci. 73:241-255.

AOAC International. 2000. Official Methods of Analysis. 17th ed. AOAC International, Arlington, VA.

Aschaffenburg, R., and J. Drewry. 1959. New procedure for the routine determination of the various non-casein proteins of milk. 3:16311637 in 15th Int. Dairy Congr. London, UK. Richard Clay and Co., Bungay, Suffolk, UK. 
Auldist, M., C. Mullins, B. O'Brien, B. T. O'Kennedy, and T. Guinee. 2002. Effect of cow breed on milk coagulation properties. Milchwissenschaft 57:140-143.

Auldist, M. J., K. A. Johnston, N. J. White, W. P. Fitzsimons, and M. J. Boland. 2004. A comparison of the composition, coagulation characteristics and cheese making capacity of milk from Friesian and Jersey dairy cows. J. Dairy Res. 71:51-57.

Bech, A. M., and R. K. Kristiansen. 1990. Milk protein polymorphism in Danish dairy cattle and the influence of genetic variants on milk yield. J. Dairy Res. 57:53-62.

Bittante, G. 2011. Modeling rennet coagulation time and curd firmness of milk. J. Dairy Sci. 94:5821-5832.

Blakesley, R. W., and J. A. Boezi. 1977. A new staining technique for proteins in polyacrylamide gels using Coomassie Brilliant Blue G250. Anal. Biochem. 82:580-582.

Bobe, G., D. C. Beitz, A. E. Freeman, and G. L. Lindberg. 1999. Associations among individual proteins and fatty acids in bovine milk as determined by correlations and factor analyses. J. Dairy Res. 66:523-536.

Boettcher, P. J., A. Caroli, A. Stella, S. Chessa, E. Budelli, F. Canavesi, S. Ghiroldi, and G. Pagnacco. 2004. Effects of casein haplotype on milk production traits in Italian Holstein and Brown Swiss Cattle. J. Dairy Sci. 87:4311-4317.

Bonfatti, V., G. Di Martino, A. Cecchinato, D. Vicario, and P. Carnier. 2010. Effects of CSN2-CSN3 haplotypes and BLG genotypes on milk production traits, protein fractions contents and protein composition of individual milk of Simmental cows. J. Dairy Sci. 93:3797-3808.

Bovenhuis, H., J. A. M. Van Arendonk, and S. Korver. 1992. Associations between milk protein polymorphisms and milk production traits. J. Dairy Sci. 75:2549-2559.

Bovenhuis, H., and J. I. Weller. 1994. Mapping and analysis of dairy cattle quantitative trait loci by maximum likelihood methodology using milk protein genes as genetic markers. Genetics 137:267-280.

Braunschweig, M., C. Hagger, G. Stranzinger, and Z. Puhan. 2000. Association between casein haplotype and milk production traits of Swiss cattle. J. Dairy Sci. 83:1387-1395.

Caroli, A. M., S. Chessa, and G. J. Erhardt. 2009. Invited review: Milk protein polymorphisms in cattle: Effect on animal breeding and human nutrition. J. Dairy Sci. 92:5335-5352.

Cipolat-Gotet, C., A. Cecchinato, M. De Marchi, M. Penasa, and G. Bittante. 2012. Comparison between mechanical and near-infrared methods for assessing coagulation properties of bovine milk. J. Dairy Sci. 95:6806-6819.

De Marchi, M., G. Bittante, R. Dal Zotto, C. Dalvit, and M. Cassandro. 2008. Effect of Holstein-Friesian and Brown Swiss breeds on quality of milk and cheese. J. Dairy Sci. 91:4092-4102.

EC (European Commission). 2004. Regulation (EC) No. 853/2004 of the European Parliament and of the Council of 29 April 2004 laying down specific hygiene rules for the hygiene of foodstuffs. Off. J. L 139:55-205.

Freyer, G., L. Panicke, Z. Liu, and G. Erhardt. 1998. Examination of genetic linkage of QTL for milk production traits to milk protein loci in a family analysis compared with results of a population analysis. Arch. Tierzucht. 41:545-552.

Gambacorta, E., C. Cosentino, M. Gambacorta, D. Marsico, and A. Perna. 2005. Podolian breed cows: Casein genotype and cheesemaking attitude in pasta filata and in hard pressed curd cheese. Pages 153-162 in Proc. 40th Symp. Intern. Zootec. From Genome to Proteome in Animal Science. Istituto Sperimentale Italiano "Lazzaro Spallanzani," Lodi, Italy.

Gambacorta, E., A. Perna, and E. Cosentino. 1994. Attitudine alla caseificazione del latte di bovine Jersey in funzione del genotipo ai loci $\alpha_{s 1}, \beta$, k-caseina. Pages 953-956 in Proc. 18th World Buiatrics Congr., Bologna, Italy. Editografica, Bologna, Italy.

Hallén, E., A. Wedholm, A. Andrén, and A. Lundén. 2008. Effect of $\beta$-casein, $\kappa$-casein and $\beta$-lactoglobulin genotypes on concentration of milk protein variants. J. Anim. Breed. Genet. 125:119-129.

Hartung, H., and E. Gernand. 1997. Investigation about cheese yielding capacity in relation to casein-polymorphism. Arch. Tierzucht 40:305-308.
Heck, J. M. L., A. Schennink, H. J. F. van Valenberg, H. Bovenhuis, M. H. P. W. Visker, J. A. M. van Arendonk, and A. C. M. van Hooijdonk. 2009. Effects of milk protein variants on the protein composition of bovine milk. J. Dairy Sci. 92:1192-1202.

Ikonen, T., H. Bovenhuis, M. Ojala, O. Ruottinen, and M. Georges. 2001. Associations between casein haplotypes and first lactation milk production traits in Finnish Ayrshire cows. J. Dairy Sci. 84:507-514.

Ikonen, T., M. Ojala, and O. Ruottinen. 1999. Associations between milk protein polymorphism and first lactation milk production traits in Finnish Ayrshire cows. J. Dairy Sci. 82:1026-1033.

Ikonen, T., M. Ojala, and E.-L. Syväoja. 1997. Effects of composite casein and beta-lactoglobulin genotypes on renneting properties and composition of bovine milk by assuming an animal model. Agric. Food Sci. Finl. 6:283-294.

International Dairy Federation. 1974. Determination of the lactose content of milk. IDF Standard no. 28. Int. Dairy Fed., Brussels, Belgium.

International Dairy Federation. 1996. Determination of fat content of milk. IDF Standard no. 1D. Int. Dairy Fed., Brussels, Belgium.

Johnson, M. E., C. M. Chen, and J. J. Jaeggi. 2001. Effect of rennet coagulation time on composition, yield, and quality of reduced-fat Cheddar cheese. J. Dairy Sci. 84:1027-1033.

Kiddy, C. A., R. E. Mccann, and R. L. Wilson. 1970. Production characteristics of cows of different milk protein genetic types. Pages 12-16 in XVIII Int. Dairy Congr., Sydney, Australia. G.W. Flowers and G. Loftus Hills, ed. Sydney, Australia.

Mariani, P., and A. Summer. 1999. Polimorfismo delle proteine ed attitudine tecnologico-casearia del latte. Sci. Tecn. Latt. Cas. 50:197-230.

Mariani, P., A. Summer, P. Formaggioni, and M. Malacarne. 2002. La qualità casearia del latte di differenti razze bovine. Riv. La Razza Bruna 1:7-13.

Marziali, A. S., and K. F. Ng-Kwai-Hang. 1986. Relationships between milk protein polymorphism and cheese yielding capacity. J. Dairy Sci. 69:1193-1201.

Matassino, D., C. M. A. Barone, P. Colatruglio, A. Zullo, and M. Mascia. 2002. Polimorfismo proteico e caratteristiche quanti-qualitative del latte di bovini allevati nel Molise. Composizione chimica. Dossier: Qualità del latte ANARB. Composizione chimica. La Razza Bruna, 5, 7. Accessed May 2015. http://www.anarb.it/dossier.

Mayer, H. K., M. Ortner, E. Tschager, and W. Ginzinger. 1997. Composite milk protein phenotypes in relation to composition and cheesemaking properties of milk. Int. Dairy J. 7:305-310.

Najera, A. I., M. de Renobales, and L. J. R. Barron. 2003. Effects of $\mathrm{pH}$, temperature, $\mathrm{CaCl} 2$ and enzyme concentrations on the rennet clotting properties of milk: A multifactorial study. Food Chem. $80: 345-352$.

Ng-Kwai-Hang, K. F. 1998. Genetic polymorphism of milk proteins: Relationships with production traits, milk composition and technological properties. Can. J. Anim. Sci. 78:131-147.

Ng-Kwai-Hang, K. F., and F. Grosclaude. 2003. Genetic polymorphism of milk proteins. Pages 739-816 in Advanced Dairy Chemistry. Vol. 1. Proteins. P. F. Fox, and P. L. H. McSweeney, ed. Kluwer Acad./Plenum Publ., New York, NY.

Ng-Kwai-Hang, K. F., J. F. Hayes, J. E. Moxley, and H. G. Monardes. 1986. Relationships between milk protein polymorphisms and major constituents in Holstein-Fresian cows. J. Dairy Sci. 69:22-26.

Nuyts-Petit, V., A. Delacroix-Buchet, and L. Vassal. 1997. Influence de trois haplotypes des caséines os1, $\beta$ et $\kappa$ fréquents en race bovine Normande sur la composition du lait et l'aptitude à la fabrication fromagère. Lait 77:625-639.

O'Brien, B., R. Mehra, J. F. Connolly, and D. Harrington. 1999. Seasonal variation in the composition of Irish manufacturing and retail milks 1. Chemical composition and renneting properties. Ir. J. Agric. Food Res. 38:53-64.

Ojala, M., T. R. Famula, and J. F. Medrano. 1997. Effect of milk protein genotypes on the variation for milk production traits of Holstein and Jersey cows in California. J. Dairy Sci. 80:1776-1785. 
Okigbo, L. M., G. H. Richardson, R. J. Brown, and C. A. Ernstrom. 1985. Variation in coagulation properties of milk from individual cows. J. Dairy Sci. 68:822-828.

Ostersen, S., J. Foldager, and J. E. Hermansen. 1997. Effects of stage of lactation, milk protein genotype and body condition at calving on protein composition and renneting properties of bovine milk. J. Dairy Res. 64:207-219.

Pabst, K. 1998. The significance of different types of milk protein (particularly k-casein) for cheesemaking. Arch. Tierzucht 41:269-276.

Pieri, R. 2010. Il Mercato del Latte. Franco Angeli, Milan, Italy.

Politis, I., and K. F. Ng-Kwai-Hang. 1988. Effects of somatic cell counts and milk composition on the coagulating properties of milk. J. Dairy Sci. 71:1740-1745.

Rahali, V., and J. L. Ménard. 1991. Influence of genetic variants of $\beta$-lactoglobulin and $\kappa$-casein on milk composition and cheesemaking properties. Lait 71:275-297.

SAS Institute. 1996. SAS User's Guide: Statistics. Version 7. SAS Institute Inc., Cary, NC.

Schaar, J., B. Hansson, and H. E. Pettersson. 1985. Effects of genetic variants of k-casein and $\beta$-lactoglobulin on cheesemaking. J. Dairy Res. 52:429-437.

Schmidt-Madsen, P. 1975. Fluoro-opto-electronic cell counting on milk. J. Dairy Res. 42:227-239.

Storry, J. E., A. S. Grandison, D. Millard, A. J. Owen, and G. D. Ford. 1983. Chemical composition and coagulating properties of renneted milks from different breeds and species of ruminant. J. Dairy Res. 50:215-229.

Strzalkowska, N., J. Krzyzewski, L. Zwierzchowski, and Z. Ryniewicz. 2002. Effects of $\kappa$-casein and $\beta$-lactoglobulin loci polymorphism, cows' age, stage of lactation and somatic cell count on daily milk yield and milk composition in Polish Black-and-White cattle. Anim. Sci. Pap. Rep. 20:21-35.

Summer, A., M. Pecorari, E. Fossa, M. Malacarne, P. Formaggioni, P. Franceschi, and P. Mariani. 2004. Protein fractions, rennet coagulation properties and Parmigiano Reggiano cheese yield of milk from Italian brown cow. Accessed May 2015. http://www.anarb.it/ Bruna2004/inglese/Presentazioni/papers/summer.pdf.

Trieu-Cuot, P., and J. C. Gripon. 1981. Electrofocusing and two dimensional electrophoresis of bovine caseins. J. Dairy Res. 48:303310.

Van den Berg, G. 1992. Genetic polymorphism of «-casein and $\beta$-lactoglobulin in relation to milk composition and processing properties. Neth. Milk Dairy J. 46:145-168.

Van Eenennaam, A., and J. F. Medrano. 1991. Milk protein polymorphisms in California dairy cattle. J. Dairy Sci. 74:1730-1735.

Velmala, R., J. Vilkki, K. Elo, and A. Mäki-Tanila. 1995. Casein haplotypes and their association with milk production traits in the Finnish Ayrshire cattle. Anim. Genet. 26:419-425.

Walsh, C. D., T. P. Guinee, D. Harrington, R. Mehra, J. Murphy, and R. J. Fitzgerald. 1998b. Cheesemaking, compositional and functional characteristics of low-moisture part-skim Mozzarella cheese from bovine milks containing $\kappa$-casein $\mathrm{AA}, \mathrm{AB}$ or $\mathrm{BB}$ genetic variants. J. Dairy Res. 65:307-315.

Walsh, C. D., T. P. Guinee, W. D. Reville, D. Harrington, J. J. Murphy, B. T. O'Kennedy, and R. J. FitzGerald. 1998a. Influence of $\kappa$-casein genetic variant on rennet gel microstructure, cheddar cheesemaking properties and casein micelle size. Int. Dairy J. 8:707-714.

Zannoni, M., and S. Annibaldi. 1981. Standardization of the renneting ability of milk by Formgraph. Sci. Tecn. Latt. Cas. 32:79-94. 